University of Pennsylvania Carey Law School

Penn Law: Legal Scholarship Repository

Faculty Scholarship at Penn Law

$2-2003$

\title{
Taxing Sunny Days: Adjusting Taxes for Regional Living Costs and Amenities
}

\author{
Michael S. Knoll \\ University of Pennsylvania Carey Law School \\ Thomas D. Griffith \\ University of Southern California
}

Follow this and additional works at: https://scholarship.law.upenn.edu/faculty_scholarship

Part of the Economic Policy Commons, Economics Commons, Law and Economics Commons, Taxation-Federal Commons, and the Tax Law Commons

\section{Repository Citation}

Knoll, Michael S. and Griffith, Thomas D., "Taxing Sunny Days: Adjusting Taxes for Regional Living Costs and Amenities" (2003). Faculty Scholarship at Penn Law. 1140.

https://scholarship.law.upenn.edu/faculty_scholarship/1140

This Article is brought to you for free and open access by Penn Law: Legal Scholarship Repository. It has been accepted for inclusion in Faculty Scholarship at Penn Law by an authorized administrator of Penn Law: Legal Scholarship Repository. For more information, please contact PennlawIR@law.upenn.edu. 


\title{
HARVARD LAW REVIEW
}

\author{
ARTICLES \\ TAXING SUNNY DAYS: \\ ADJUSTING TAXES FOR REGIONAL \\ LIVING COSTS AND AMENITIES
}

\section{Michael S. Knoll* and Thomas D. Griffith**}

The federal income tax code does not adjust individuals' tax burdens for 1 differences in regional living costs. Thus, a married couple with an annual income of $\$ 100,000$ will pay the same amount in federal income tax and thus have the same after-tax income - whether they live in New York City or Atlanta. However, because the cost of living is higher in New York, ${ }^{1}$ the Atlanta family will enjoy a better standard of living. ${ }^{2}$ To achieve the same standard of living, the New York family would not only have to earn more to cover their higher living costs, but also, because personal living expenses are generally not deductible, ${ }^{3}$ they would have to earn more to cover the additional taxes they would owe on their higher earnings. ${ }^{4}$ Ordinary citizens often view this state of affairs as unfair and sug-

* Professor of Law and Real Estate, University of Pennsylvania Law School and the Wharton School.

** John B. Milliken Professor of Taxation, University of Southern California Law School. Thanks to Linda Beres, David Bradford, Charlotte Crane, Jeff Gordon, Bruce Johnsen, Louis Kaplow, Deborah Paul, Dan Shaviro, Reed Shuldiner, audiences at Cardozo, George Mason, Georgetown, Northwestern, NYU, Penn, Toronto, Vanderbilt, and Virginia Law Schools, and at the Schulich and Wharton Schools of Business, and participants at the Harvard and Southern California Tax Policy Seminars. We also thank Al Dong, Peter Sanchez, and Dara Zweig for their assistance with the research.

1 The cost of living in New York City is more than double that in Atlanta. See infra Appendix I, pp. 1021-23.

2 This assumes that a taxpayer's "standard of living” does not include the consumption value, if any, of living in New York rather than in Atlanta. Consumption "amenities," which might reduce or eliminate apparent differences in living standards, are described in Part VII, infra pp. 1007-17.

3 I.R.C. § 262(a) (2000). There are some exceptions, including, for example, medical expenses in excess of 7.5\% of adjusted gross income (AGI), I.R.C. § 213(a), and casualty losses in excess of 10\% of AGI, I.R.C. $\S 165(\mathrm{c})(3),(\mathrm{h})(2)$.

4 Why living costs differ across regions and the relationship between differences in living costs and productivity are discussed in Part I, infra pp. 989-93. 
gest that personal income taxes should be adjusted for differences in regional living costs by assessing tax on a taxpayer's "real" income. ${ }^{5}$

Tax commentators are less sure. Their intuition is that no adjustment is necessary because there is no unfairness. They reason that although taxpayers in high-cost regions earn more and so pay higher nominal taxes, the real value of their incomes and tax burdens (measured by the goods and services they could otherwise purchase with their tax dollars) is generally no higher than that of taxpayers in low-cost regions. Viewed in terms of ability to pay, ${ }^{6}$ taxpayers are treated no differently based on their locations, and thus there is no need for adjustments. ${ }^{7}$

In our view, fairness arguments - either for or against adjusting the tax burden to account for differences in regional living costs - are uneasy at best because competition from interregional migration tends to eliminate differences in living standards for individuals with similar skills and drive. ${ }^{8}$ The tendency for migration to eliminate interregional differences in living standards robs ability-to-pay arguments of their moral force on the question of how the tax burden should be distributed across regions. ${ }^{9}$

Ability to pay, however, is not the full story. In this Article, we show that the failure to adjust individuals' tax liabilities for different regional living costs misallocates capital and labor throughout the economy, discouraging investment and employment in high-cost regions and encouraging it in low-cost regions. ${ }^{10}$ Thus, to eliminate a tax-induced bias against

5 See, e.g., David A. Levy, Index Federal Income Taxes, NewSDAY, Apr. 2, 1993, at 66 (describing a bill he introduced in Congress in 1993 that would have indexed federal income tax rate brackets to regional costs of living by imposing a tax on each taxpayer's gross income divided by his local cost of living); Zoe Lofgren, Government Shouldn't Tax Income Before You Get It, SAN JOSE BUS. J., Apr. 16, 2001, http://sanjose.bizjournals.com/sanjose/stories/2001/04/16/ editorial3.html (arguing that the tax code discriminates against taxpayers in regions with high costs of living because tax credits and other benefits are less valuable to them than they are to taxpayers in regions with low costs of living). The only explicit concession in the federal income tax to differences in living costs across regions is the per diem allowance for unsubstantiated expenses incurred by government employees while on temporary assignment away from home. The allowance is greater for regions with a higher cost of living. See General Services Administration, Domestic Per Diem Rates, at http://www.policyworks.gov/perdiem (last visited Jan. 11, 2003).

6 "Ability to pay" is the principle that the tax burden should be distributed according to individuals' capacities to contribute to the collective good. See DAVID F. BRADFORD, UNTANGLING THE INCOME TAX 150 (1986).

7 Perhaps it is because of their intuition that the status quo's treatment of differences in regional living costs is correct that there has been so little serious analysis of the income tax consequences of costof-living differences. A notable exception is an excellent recent article, Louis Kaplow, Regional Costof-Living Adjustments in Tax/Transfer Schemes, 51 TAX L. REV. 175 (1996). However, because Professor Kaplow assumes a static economy with no market adjustments, see id. at 183, he does not consider the tax system's impact on total productivity, which is the focus of our analysis. 95.

8 This is so regardless of how tax burdens are distributed across regions. See infra Part II, pp. 993-

9 Where migration in both directions is not sufficient to eliminate differences in living standards, such as across income classes, ability-to-pay arguments might still have force.

10 See infra Part IV, pp. 997-1000. 
high-cost regions, we show that the income tax needs to be adjusted for differences in regional living costs. ${ }^{11}$

Regional differences in consumption amenities complicate our analysis. ${ }^{12}$ Consumption amenities, which include sunny weather, good schools, and access to entertainment and recreation, can be reflected in either lower salaries or higher living costs. Differences in amenities reflected in the cost of living do not misallocate resources. ${ }^{13}$ Yet, differences in consumption amenities reflected in salaries introduce a second misallocation. Other things equal, employers and employees both prefer for employees to receive some of their compensation in the form of (untaxed) amenities rather than (taxed) salary. Amenities that are reflected in lower salaries misallocate capital and labor by encouraging production in high-amenity/low-salary regions and discouraging it in low-amenity/high-salary regions. ${ }^{14}$

Surprisingly, a simple adjustment will eliminate, in theory at least, the inefficiencies flowing from the tax system's failure to account for differences in both regional living costs and amenities. That adjustment calls for dividing each taxpayer's income by the region's relative before-tax salary level. ${ }^{15}$ Such an adjustment assesses the same nominal tax on taxpayers with the same standard of living across regions, thereby ensuring that tax considerations neither encourage nor discourage taxpayers from locating in any region. ${ }^{16}$

\section{DIFFERENCES IN LIVING COSTS AND PRODUCTIVITY ACROSS REGIONS}

This Part describes, first, how living costs can differ across regions and, second, the relationships between living costs and salaries and between living costs and the return to capital.

\section{A. Why Living Costs Differ Across Regions}

The cost of living varies substantially across the United States. ${ }^{17}$ The New York metropolitan area is the most expensive; Kingsport, Tennessee is the least expensive. ${ }^{18}$ To achieve a standard of living equivalent to an

\footnotetext{
11 Part IV describes how to make the appropriate adjustment.

12 See infra Part VII, pp. 1007-17.

13 See infra section VII.A.2, pp. 1010-12.

14 See infra section VII.A.1, pp. 1008-10.

15 As discussed in Part VI, pp. 1005-07, only the taxpayer's location-specific income (principally earned income) should be adjusted for regional differences in living costs. Non-location-specific income (principally income from capital) should not be adjusted.

16 See infra Parts V, pp. 1000-05, and VII, pp. 1007-17.

17 See Walter W. McMahon, Geographical Cost of Living Differences: An Update, 19 AREUEA: J. AM. REAL EST. \& URB. ECON. Ass'N 426, 426 (1991).

18 ACCRA COST OF Living InDEX, Aug. 2002, at 1.7, 1.10. The best data on United States regional costs of living is compiled by ACCRA, a nonprofit organization comprising the research staffs of chambers of commerce and other organizations. ACCRA compiles data quarterly from local chambers
} 
annual after-tax income of $\$ 40,000$ in the average U.S. city requires about $\$ 88,000$ after tax in New York. ${ }^{19}$ To obtain the same standard of living in Kingsport requires only about $\$ 34,000 .{ }^{20}$ The cost of living in a region is usually expressed as a multiple of the national average. Thus, the cost of living in New York is 2.20 and in Kingsport is $0.85 .^{21}$

The cost of living is defined as the cost to a typical consumer of maintaining a fixed standard of living. ${ }^{22}$ It is calculated as the cost to such a consumer of purchasing a fixed basket of goods and services. ${ }^{23}$ The cost of living differs across regions because the prices of the constituent items differ. These items are commonly divided into two broad classes: housing, and other goods and services.

The costs of other goods and services differ principally because of supply differences. Transportation costs, which raise the cost of most goods and services in less accessible areas, help explain the increased cost of living in Alaska and Hawaii. ${ }^{24}$ A higher cost of living can also result from scarcity of a particular good in a region. The costs of providing water and energy, for example, vary substantially from region to region. ${ }^{25}$ In addition, maintaining the same standard of living might also require more of a particular item in one region than in another. For example, the costs of adequate heating in frigid areas and cooling in sweltering areas increase living costs in those areas. ${ }^{26}$

Housing costs vary principally because of differences in demand. Housing responds differently to changes in demand than most goods do. Increased demand for most goods other than housing quickly brings an increase in supply to a region with little long-run effect on price. ${ }^{27}$ The demand for clothing, cars, and electronic equipment, for example, is higher in more densely populated areas, but prices for such items are about the same as in thinly populated areas. Increased demand for housing, by con-

\footnotetext{
of commerce that have volunteered to price a list of goods and services in their communities. See id. at i-ii.

19 See id. at ii, 1.7.

20 See id. at ii, 1.10

21 See infra Appendix I, pp. 1021-23.

22 See ACCRA COST OF LIVING INDEX, supra note 18, at i-ii.

23 Bureau of Labor Statistics, U.S. DeP'T of LABOR, MEAsurement Issues in the CONSUMER PRICE INDEX § 2 (June 1997), http://stats.bls.gov/cpi/cpigm697.htm.

24 See infra Appendix I, pp. 1021-23.

25 See id.

26 Although the theoretically correct cost of living would take account of differences in the consumption basket across regions, cost of living indexes are calculated using the same basket in all regions. See id.; ACCRA COST OF LIVING INDEX, supra note 18, at i, iii.

27 Supply is said to be highly elastic. This assumption is standard in the regional economics literature. See, e.g., Joseph Gyourko et al., Quality of Life and Environmental Comparisons, in 3 HANDBOOK OF REgIONAL AND URBAN ECONOMICS 1413, 1416-17 (Paul Cheshire \& Edwin S. Mills eds., 1999).
} 
trast, usually has a larger effect on price because the amount of land is fixed. ${ }^{28}$

The demand for housing can be high for two reasons. First, the region might have strong consumption amenities. Consumption amenities include both public goods - such as gorgeous scenery, good public schools, a low crime rate, and pollution-free air and water - and private goods - such as theaters, restaurants, and professional sports teams. Demand for housing is high in areas with strong positive amenities. For example, housing on the coast, especially outside of flood plains, is expensive. Conversely, demand for housing is low in areas with strong negative amenities, such as high pollution levels, bad weather, and high crime rates.

A second reason for high housing prices is that the region may have production amenities that make workers more productive in their jobs and therefore allow them to earn more than they would if they lived elsewhere. Workers might be more productive because of local resources such as cheap energy, good transportation, and proximity to markets. Workers also might be more productive because of their proximity to other workers. ${ }^{29}$

\section{B. The Relationships Between Living Costs and Salaries and Between Living Costs and the Return to Capital}

The United States is a highly mobile society in which individuals can easily change jobs and locations. Such mobility tends to equalize living standards. Accordingly, in the United States, there has been a "persistent and strong" convergence in regional living standards. ${ }^{30}$

Equalizing living standards is not the same as equalizing nominal incomes. Differences in nominal incomes are likely to persist as long as living costs differ. Ignoring, for the moment, differences in consumption amenities, and assuming that regional living standards have fully converged

\footnotetext{
28 The assumption that supply of land is highly inelastic is standard in the literature. See, e.g., id.

29 There appear to be large positive productivity externalities for workers in many fields and even across fields. These externalities make the productivity of many skilled workers higher in urban areas than in rural areas. See generally EdWARD L. GlaESER \& DAVID C. MARÉ, CitIES AND SKILLS (NBER Discussion Paper No. 1678, 1994) (arguing that workers acquire skills faster in dense environments). If there are such externalities, subsidies to employees or employers in high-cost areas might be appropriate. These subsidies, as well as any taxes that might be appropriate to offset congestion costs, are beyond the scope of this article.

30 Matthew P. Drennan et al., The Interruption of Income Convergence and Income Growth in Large Cities in the 1980s, 33 URB. STUD. 63, 63 (1996) ("II]n the historical experience of the US, the convergence of regional income, whatever the measure of income used, has been persistent and strong." (citations omitted)). Theorists predict that living standards will converge over time. See, e.g., J.R. HiCKS, THE THEORY OF WAGES 37-39 (2d ed. 1963). And numerous academic studies support the theory as applied to the United States. See, e.g., Robert J. Barro \& Xavier Sala-i-Martin, Convergence Across States and Regions, 1 BroOKIngs PaPERS On ECON. ACTIVITY 107, 107-08 (1991); George H. Borts, The Equalization of Returns and Regional Economic Growth, 50 AM. Econ. REV. 319, 343 (1960). A notable exception to this long-term convergence was the divergence in regional incomes during the 1980s. See Drennan et al., supra, at 63.
} 
to an equilibrium, the relationship between real after-tax income for any given occupation in region $i$ and the region's relative cost of living, $C_{i},{ }^{31}$ is given by:

$$
\text { Real after-tax } \text { income }_{i}=\frac{\text { Nominal after-tax income }}{i}=K \text { for all } i \text {, }
$$

where $K$ is a constant across regions for that occupation. Thus, in equilibrium, there is a direct relationship between nominal after-tax income and relative living costs: increasing relative living costs by $50 \%$ will increase nominal after-tax income by $50 \% .^{32}$

Financial capital is even more mobile than labor; it moves easily, not just throughout the United States, but throughout the world. Moreover, financial capital can be employed far from where its owner lives. Today, vast amounts of capital can be moved quickly to take advantage of even very small differences in return. This mobility quickly tends to drive down excess profits to capital in any location to ordinary levels. Thus, capital owners generally will earn only an (ex ante) ordinary return on their investments, with any differences in return accounted for by differences in risk. Competition thus tends to make the risk-adjusted, after-tax return to capital the same, regardless of where it is located, so that:

$$
\text { Risk-adjusted after-tax return to } \text { capital }_{i}=k \text { for all } i \text {, }
$$

where $k$ is a constant across regions. ${ }^{33}$

In summary, in equilibrium, nominal after-tax wages are proportionate to living costs, but the nominal after-tax return to capital is fixed and independent of living costs.

\section{THE NO-TAX BENCHMARK}

This Part provides a simple example of how resources are allocated in an economy without taxes. In this and the four following Parts, we assume that the value of consumption amenities is constant across regions. ${ }^{34}$ Cost of living differences are a result either of differential prices for some

31 The region's relative cost of living, simply called the cost of living throughout this Article, and denoted by $C_{i}$, is given by the following formula:

$$
C_{i}=\frac{\text { Region } i \text { Cost of Living }}{\text { National Average Cost of Living }} .
$$

The index is normalized with a mean of one.

32 This is consistent with the standard assumption in the urban economics literature that the market through which people choose where to live is in equilibrium. See Gyourko et al., supra note 27, at 1417.

33 This is consistent with the standard assumption in the regional economics literature that capital owners are indifferent to where their capital is employed. See id.

34 We introduce differences in amenities in Part VII, infra pp. 1007-17. 
goods and services other than housing, or of different population densities producing different demands for housing. In either case, such differences in living costs will be reflected in different levels of employee productivity at the margin.

Consider an economy with three regions - Cheap, Middling, and Pricey - each with a different cost of living. An after-tax income of $\$ 50,000$ in Middling has the same purchasing power as $\$ 40,000$ in Cheap or $\$ 60,000$ in Pricey. Thus, if Middling represents the national average cost of living, Cheap will have a cost of living that is $80 \%$ of the national average and Pricey a cost that is $120 \%$ of the average. ${ }^{35}$

Consider someone in such an economy who has been offered equivalent jobs in the three regions. The jobs, all of which provide the same standard of living, pay $\$ 40,000$ in Cheap, $\$ 50,000$ in Middling, and $\$ 60,000$ in Pricey. This is illustrated in Table 1A below.

As Table $1 \mathrm{~A}$ illustrates, the jobs pay different nominal salaries, but each pays a real salary of $\$ 50,000$. Accordingly, an individual choosing where to work solely on the basis of her standard of living would be indifferent among the three jobs.

Imagine that the employer is a large, national business with employees in all three regions and that its ownership is widely dispersed. The employer combines hired capital and labor to produce goods or services that it sells in a competitive national market. If the employer generates the same revenue by hiring an additional employee in any

TABLE 1A. NO-TAX BENCHMARK: EMPLOYEE's INCOME

\begin{tabular}{||l|c|c|c||}
\hline & Cheap & Middling & Pricey \\
\hline \hline Nominal Income & $\$ 40,000$ & $\$ 50,000$ & $\$ 60,000$ \\
\hline Cost of Living & 0.8 & 1 & 1.2 \\
\hline $\begin{array}{l}\text { Real Income } \\
\text { (Adjusted for } \\
\text { Cost of Living) }\end{array}$ & $\$ 50,000$ & $\$ 50,000$ & $\$ 50,000$ \\
\hline
\end{tabular}

\footnotetext{
35 To simplify the discussion, we assume throughout this Article that a serviceable index of relative living costs, $C_{i}$, has been compiled. This is not necessarily an easy task, and constructing a perfect index is impossible. For discussions of the theoretical impossibility of a perfect index and difficulties in constructing serviceable indexes, see Gen. Accounting Office, Poverty MEAsurement: AdJUSTING FOR GEOGRAPHIC COST-OF-LIVING DifFERENCES 3-6 (Report No. GAO/GGD-95-64, 1995), available at http://www.gao.gov/archive/1995/gg95064.pdf; and Kaplow, supra note 7, at 18889. See also infra section VIII.B.1, p. 1019.
} 
region, it would benefit most by hiring the next employee in Cheap, because it can pay that additional employee the least. Thus, for employers to be indifferent as to the region in which the company hires an additional employee, the difference in the corporation's revenue across regions must equal the difference in the employee's salary. Hence, the firm in Table 1A would be indifferent as to where it hired an additional employee only if the employee generated $\$ 10,000$ more revenue for the firm in Middling than in Cheap, and \$10,000 more in Pricey than in Middling.

In contrast to employees, who take into account both the salary and the local cost of living in deciding where to work, capital owners take into account only the return to capital (appropriately adjusted for risk) in deciding where to invest. Most individuals must live close to where they work, whereas capital owners can invest their capital almost anywhere they choose and are not constrained to invest close to home. Because capital owners can separate their location and investment decisions, in equilibrium, the risk-adjusted return to capital is equal across regions. ${ }^{36}$ If it is not, capital will leave regions where the return is low and move to regions where it is high. Thus, the productivity of capital must be constant across regions and must equal its marginal return. Accordingly, if the equilibrium return to capital in Middling is $\$ 22,500$, it is also \$22,500 in Cheap and Pricey. ${ }^{37}$ This is illustrated by Table 1B.

TABLE 1B. NO-TAX BENCHMARK: RETURN TO CAPITAL

\begin{tabular}{|l|c|c|c|}
\hline \hline & Cheap & Middling & Pricey \\
\hline Return to Capital & $\$ 22,500$ & $\$ 22,500$ & $\$ 22,500$ \\
\hline
\end{tabular}

This example (Tables 1A and 1B) serves as a benchmark to define the no-tax equilibrium. Against this benchmark, it is possible to determine how the income tax affects the allocation of resources across regions.

This benchmark equilibrium also implies a capital-labor ratio in each region. Two standard assumptions in economics are that the marginal product of labor increases as the amount of capital available to each employee rises ${ }^{38}$ and that, in equilibrium, labor and capital are paid the value

\footnotetext{
36 There are differences in political risk across countries that affect the expected return. However, any differences in political risk within the United States are probably very small. Throughout this Article, we have assumed that the level of risk across regions is constant. This assumption is not necessary, but it simplifies the exposition.

37 The return to capital is for one unit of capital. For example, if a unit of capital is $\$ 300,000$, then the rate of return on capital is $7.5 \%$.

38 See Paul A. Samuelson \& William D. Nordhaus, Economics 124 (15th ed. 1995).
} 
of their marginal products. ${ }^{39}$ We will use these assumptions to determine how the equilibria with different tax systems compare to the no-tax benchmark equilibrium and to each other.

\section{THE IMPACT OF TAXES ON THE INTERREGIONAL ALLOCATION OF RESOURCES}

To understand how taxes affect the allocation of resources throughout the economy, we assume that the government imposes a flat $20 \%$ income tax (without a zero-bracket amount) on both capital and earned income. ${ }^{40}$ To focus on the tax side of the issue, we further assume that the tax revenue raised from each taxpayer is not spent purchasing goods and services in her community, where the real purchasing power would depend on her local living costs. Instead, we assume that the revenue is spent in a manner that is independent of where it is raised. Conceptually, it might be simplest to think of the government raising revenue to spend generating national public goods, such as foreign aid, national defense, public parks, or the Washington bureaucracy. In all of these instances, the purchasing power of the tax revenue does not depend on where the taxpayers who provided the funds reside. ${ }^{41}$

As in the no-tax benchmark, we assume that labor and capital are mobile and that there are no regional differences in the value of consumption amenities. The assumption that labor is mobile implies that, in equilibrium, real after-tax salaries will be in proportion to living costs. The assumption that capital is mobile implies that the equilibrium after-tax return to capital will be equal across regions. Once again, equilibrium is established when individuals have no incentive to move and capital owners have no incentive to shift their capital.

Under these assumptions, equilibrium gross salaries are unchanged by the tax. Each employee, however, must pay $20 \%$ of her salary in taxes, which leaves her with $20 \%$ less to spend on consumption. The before- and after-tax incomes of employees in each region are shown in Table 2A.

39 See Jack Hirshleifer \& DAVID Hirshleifer, Price TheORY AND APPlications 316-20 (6th ed. 1998). This assumption holds as long as there is no monopoly power in the factor markets. HIRSHLEIFER \& HIRSHLEIFER, supra, at 320.

40 We also assume that there is no separate entity-level income tax like the corporate income tax, but that all entity-level income is passed through to individual owners for the purpose of calculating taxable income.

41 We relax this assumption later. Appendix III, pp. 1023-25, describes how to construct the efficiency-producing multiplier when taxes are used to provide taxpayers with local goods and services. We also assume that the economic incidence of the tax is identical to the payment obligations imposed by the tax. Again, this assumption does not affect the results, but it does simplify the exposition. 
TABLE 2A. 20\% TAX: EMPLOYEE'S INCOME

\begin{tabular}{|l|c|c|c||}
\hline & Cheap & Middling & Pricey \\
\hline \hline Before-Tax Income & $\$ 40,000$ & $\$ 50,000$ & $\$ 60,000$ \\
\hline Tax (20\%) & $\$ 8000$ & $\$ 10,000$ & $\$ 12,000$ \\
\hline $\begin{array}{l}\text { Nominal After-Tax } \\
\text { Income }\end{array}$ & $\$ 32,000$ & $\$ 40,000$ & $\$ 48,000$ \\
\hline Cost of Living & 0.8 & 1 & 1.2 \\
\hline $\begin{array}{l}\text { Real After-Tax In- } \\
\text { come }\end{array}$ & $\$ 40,000$ & $\$ 40,000$ & $\$ 40,000$ \\
\hline
\end{tabular}

The gross return to capital is also unchanged - it remains $\$ 22,500$ in each region. The net return to capital, therefore, is reduced by $\$ 4500$, the tax paid, to $\$ 18,000$. This is illustrated by Table $2 \mathrm{~B}$ below.

Tables $2 \mathrm{~A}$ and $2 \mathrm{~B}$ describe an equilibrium - a situation in which there is no incentive for resources to move. Employees have no incentive to move because their real after-tax income is $\$ 40,000$ in each region. Capital owners have no incentive to shift their capital because they receive $\$ 18,000$ after tax in each region.

Most importantly, the income tax has not shifted resources: the allocation of resources is the same both before and after imposition of the tax. Resources do not shift because imposition of the tax changes

TABLE 2B. 20\% TAX: RETURN TO CAPITAL

\begin{tabular}{|l|c|c|c||}
\hline & Cheap & Middling & Pricey \\
\hline \hline Taxable Income & $\$ 22,500$ & $\$ 22,500$ & $\$ 22,500$ \\
\hline Tax (20\%) & $\$ 4500$ & $\$ 4500$ & $\$ 4500$ \\
\hline $\begin{array}{l}\text { After-Tax Return to } \\
\text { Capital }\end{array}$ & $\$ 18,000$ & $\$ 18,000$ & $\$ 18,000$ \\
\hline
\end{tabular}

neither pre-tax salaries nor the pre-tax return to capital in any region. ${ }^{42}$

42 The productivity of labor depends on the amount of both labor and capital; likewise, the productivity of capital depends on the amount of both capital and labor. In equilibrium, the wage or return to each factor equals the value of its marginal product, which depends on the amount of both labor and capital. Thus, since gross wages and gross returns are unchanged by the income tax (compare Table 


\section{HOW THE INCOME TAX Misallocates ResOuRCES}

In Part II, we showed that in the absence of an income tax the allocation of resources across regions is efficient. ${ }^{43}$ In Part III, we showed that the allocation with a flat income tax is identical to that without an income tax. It might, therefore, be thought that the allocation with a flat income tax is also efficient. The argument is simple enough: the interregional allocation in a no-tax world is efficient; imposing a flat income tax does not change that allocation; therefore, the allocation of resources across regions with a flat income tax is efficient.

Surprisingly, however, that conclusion is incorrect. Although a flat tax does not change the allocation of resources, it causes that allocation to become inefficient. This Part demonstrates this claim and explains the intuition behind it.

An allocation of resources is efficient if it is not possible to reallocate resources and improve the welfare of at least one party without making at least one other party worse off. ${ }^{44}$ Thus, an allocation is inefficient if it is possible, by reallocating resources, to improve the welfare of some or all individuals without reducing anyone's welfare. ${ }^{45}$

Table 2A makes it easy to see that the interregional allocation of resources with an income tax is inefficient. Removing one employee from

1A, row 1, supra p. 994, with Table 2A, row 1, supra p. 996, and Table 1B, row 1, supra p. 995, with Table 2B, row 1, supra p. 997), the value of the marginal product of each factor is also unchanged.

This implies that resources are not reallocated across regions: the tax reduces the after-tax salary in each region by $20 \%$. As a result, the after-tax income in Pricey is still $20 \%$ larger than that in Middling, whereas the after-tax income in Cheap is still $20 \%$ smaller than that in Middling. Thus, after adjusting for the regional cost of living differences of $20 \%$, employees in each region will have the same standard of living.

43 Our analysis in Part II, supra pp. 993-95, assumed that there were no regional differences in the value of consumption amenities. In section VII.A.2, infra pp. 1010-12, we show that the tax-free allocation of resources is still efficient when the value of amenities is allowed to differ across regions.

44 This is the standard definition of Pareto efficiency. See, e.g., JOHN HICKS, The Foundations of Welfare Economics, in WEALTH AND WELFARE 59, 64 (1981); Allan M. Feldman, Welfare Economics, in 4 The New PALgRAVE: A DiCTIONARY OF ECONOMiCs 889, 890 (John Eatwell et al. eds., 1987). Kaldor-Hicks efficiency occurs when it is impossible to reallocate resources such that the winners would still come out ahead if the losers were compensated for their losses. HICKS, supra, at 75-76; NICHOLAS KALDOR, Welfare Propositions in Economics, in ESSAYS ON VALUE AND DISTRIBUTION 143-45 (2d ed. 1980); Feldman, supra, at 892. In the simple example we use, the two definitions differ only to the extent that there are transitional gains and losses, which we briefly discuss in section VIII.A, infra p. 1018.

45 Efficiency is especially desirable in situations, such as this one, in which in the long run no one benefits from an inefficient allocation of resources. The movement of persons and capital eliminates differences in real after-tax income and the return to capital. As a result, the costs of an inefficient allocation of resources are likely to be widely disbursed, as are the potential benefits from an efficient allocation. Boris Bittker provides an amusing and insightful discussion of the tendency of markets to capitalize tax benefits into prices, thereby eliminating the profit from purchasing tax-advantaged assets. See BORIS BITTKER, Tax Shelters and Tax Capitalization or Does the Early Bird Get a Free Lunch?, in COLlECTED LEGAL EsSAYs 547 (1989) (describing how the value of the mortgage interest deduction has been capitalized into home prices). 
Cheap reduces gross revenue by $\$ 40,000$. That reduction is split between a decline in the after-tax payments to labor $(\$ 32,000)$ and a loss in tax revenue (\$8000). Adding one employee to Pricey increases gross revenue by $\$ 60,000$. Out of this amount, it is possible to compensate the employee $\left(\$ 48,000^{46}\right)$ and the Treasury $\left(\$ 8000^{47}\right)$ and still have $\$ 4000$ remaining. Because it is possible to shift one employee from Cheap to Pricey, compensate all parties for their losses, and still have $\$ 4000$ to distribute, the original allocation of resources is not efficient. Thus, the imposition of a flat income tax, even though it does not reallocate resources, causes that allocation to become inefficient.

The inefficiency caused by the income tax has several properties. First, it has a direction. Our model employs two factors of production - labor and capital - that are in fixed supply. ${ }^{48}$ Employees decide where to live and work, and capital owners decide where to invest their capital. Equilibrium occurs when the real after-tax wage and the nominal after-tax return to capital are constant across regions. The resulting equilibrium is characterized by the labor-capital ratio in each region. Relative to the efficient allocation of resources, labor is used too intensively relative to capital in Cheap and labor is not used intensively enough relative to capital in Pricey. This conclusion follows from the demonstration that shifting one employee from Cheap to Pricey (thereby lowering the labor-capital ratio in Cheap and raising it in Pricey) is efficiency-enhancing.

Second, the efficiency loss can be quantified. At the margin, that loss is $\$ 4000$ - exactly the gain that could be produced by shifting one employee from Cheap to Pricey. As more employees relocate, the potential gain from shifting one more employee declines as wages fall in Pricey and rise in Cheap. The total inefficiency loss is the sum of the foregone gains. ${ }^{49}$

Third, one can identify the source of the inefficiency. An employee located in Cheap pays $\$ 8000$ in tax, an employee in Middling pays $\$ 10,000$, and an employee in Pricey pays $\$ 12,000.5^{5}$ The difference in tax thus raises the cost to employers of hiring employees in Pricey and reduces that cost in Cheap. It is this tax-induced increased cost of hiring in Pricey and

46 The cost of living in Pricey is $150 \%$ of that in Cheap. Thus, it takes an after-tax salary of $\$ 48,000$ in Pricey to provide the same standard of living as an after-tax salary of $\$ 32,000$ in Cheap.

47 It takes $\$ 8000$ to compensate the tax collector (not $\$ 12,000$ ) because tax revenue is not spent at the local cost of living.

48 One effect of imposing an income tax is to reduce the returns to labor and capital in the economy. These reductions are likely to cause resources to leave the economy by going offshore or withdrawing from the market. Because this well-known effect is separate from the effect that we are examining the misallocation across regions brought about by the income tax — we assume that the income tax does not cause resources to be withdrawn from the market. This isolates the impact of the income tax on the allocation of resources across regions.

49 In theory, the total efficiency loss can be measured if the responsiveness of wages to labor in each region can be estimated.

50 See supra Table 2A, row 2, supra p. 996. 
decreased cost in Cheap that is the source of the inefficiency. ${ }^{51}$ As compared to employees in Middling, the tax system imposes an additional tax of \$2000 on employees in Pricey and grants a \$2000 subsidy to employees in Cheap. The additional tax imposed on employees located in high-cost regions is inefficient because it will prevent employers from hiring employees who are sufficiently more productive to cover their additional living expenses, but are not sufficiently more productive to cover their additional taxes as well. The effect is the opposite for low-cost regions: the tax reduction granted to employees located in low-cost regions is inefficient because it will induce employers to hire employees who are not sufficiently productive to cover their incremental living expenses without the tax subsidy. Thus, when living costs vary regionally, a flat tax discourages employees from

locating in high-cost regions and encourages them to locate in low-cost regions. ${ }^{52}$

In effect, the tax creates a wedge between social and private benefits across regions. The movement of individuals will ensure that private benefits (the real after-tax standard of living) are equal across regions (in the example, $\$ 40,000$ in each region ${ }^{53}$ ). Interregional efficiency requires that total social benefits are equal when private benefits are equal. In the model, tax revenues are the only social benefits that are not also private benefits. It is, accordingly, because tax revenues are greater in high-cost regions (\$12,000 in Pricey) than in low-cost regions (\$8000 in Cheap) that the flat tax is inefficient. (That is to say, the total social benefit is $\$ 52,000$ if an additional person locates in Pricey, but only $\$ 48,000$ if she locates in Cheap. ${ }^{54}$ )

The reason imposing a flat tax causes the allocation of resources to become inefficient without changing that allocation is subtle. Without an income tax, the employee's entire gross salary is spent at her cost of living; however, with an income tax, only the after-tax portion of that salary is spent at her cost of living. The portion of her salary that is paid in taxes is spent outside of the region and in a manner that is independent of her cost of living. Thus, in the example, an employee in Pricey with \$48,000 can

51 Our analysis assumes that living costs are not tax-deductible. However, taxpayers who itemize their deductions can deduct some living costs, such as home mortgage interest, I.R.C. § 163(h)(3) (2000), housing expenses incurred while living abroad in excess of an amount determined by a formula, id. § 911(c)(3), and state and local taxes, id. § 164. These deductions are efficiency-enhancing to the extent that they are larger where living costs are higher. At best, however, they are a second-best solution. By encouraging taxpayers to spend more on deductible living costs and less on nondeductible living costs, they also reduce efficiency.

52 A progressive income tax schedule, in which the marginal tax rate increases with income, exacerbates this effect because the higher tax rate further increases the tax on higher income employees, who are likely to live in high-cost regions.

53 See supra Table 2A, row 5, supra p. 996.

54 See supra Table 2A, rows 2 and 5, supra p. 996. 
purchase the same goods and services as an employee in Middling with $\$ 40,000$, or as an employee in Cheap with $\$ 32,000$. In contrast, the government purchases more goods and services with the $\$ 12,000$ raised in Pricey than with the $\$ 10,000$ raised in Middling, and it purchases more with the $\$ 10,000$ raised in Middling than with the $\$ 8000$ raised in Cheap. ${ }^{55}$ This difference - that the purchasing power of a dollar of after-tax income is in proportion to the cost of living in the region where it was earned, while the purchasing power of a dollar of tax revenue is independent of the cost of living in the region where it was raised - is the source of the wedge between social and private benefits that creates the interregional inefficiency.

\section{AdJusting TAxes To REFLECT DiffERENCES IN REgIONAL LiVING COSTS}

Part IV demonstrated that an income tax misallocates resources across regions with different living costs because employees in high-cost regions earn more and thus pay higher nominal taxes than employees in low-cost regions. The additional taxes that are paid when an employer hires an additional employee in a high-cost region discourages employers from hiring in high-cost regions and encourages them to hire in low-cost regions. It follows, therefore, that to achieve an efficient allocation of resources, employees with the same real after-tax income should pay the same nominal tax regardless of where they locate. ${ }^{56}$ This Part describes how to modify the income tax to produce the efficient allocation of resources across regions.

So that resources are allocated efficiently across regions, individuals should be taxed on adjusted taxable income, which is defined as follows:

$$
\text { Adjusted Taxable Income }=\text { Taxable Income } \times m_{i} \text {, }
$$

where $m_{i}$ is the multiplier for region $i$. In the simple examples used in this Article, we assume a flat tax without a zero-bracket amount. ${ }^{57}$ Under such a flat tax, increasing taxable income by the multiplier is equivalent to increasing the tax rate by the same multiplier:

$$
\text { Effective Tax Rate }=\text { Statutory Tax Rate } \times m_{i} .
$$

\footnotetext{
55 Since employees have the same real income in all three regions, total output (measured as the sum of personal real after-tax income plus government purchases of real goods and services) is highest in Pricey and lowest in Cheap.

56 A head tax, for instance, would eliminate the interregional inefficiency; however, it would impose the same tax on people with different standards of living. The adjustment proposed in this Article would impose the same tax on individuals with the same standard of living, while permitting the tax system to impose different tax liabilities on people with different standards of living.

57 Tax progressivity is considered infra note 115.
} 
As shown in Part IV, the misallocation of resources will be prevented if all employees with the same real after-tax income pay the same amount in tax regardless of where they live. In this case, taxes will neither subsidize nor penalize the decision to hire people in low- or high-cost regions.

This Part describes two methods for calculating the efficiency-producing multiplier: one uses the relative salary level and the other uses the relative cost of living. In equilibrium, where living standards are equal across regions, ${ }^{58}$ the two methods produce the same result.

\section{A. Relative Salary Method}

The relative-salary multiplier is designed to ensure that employees with the same real after-tax income pay the same amount in tax regardless of where they locate. This can be achieved by dividing each employee's income by the ratio of her salary to the equivalent salary in a region with the national average cost of living. Denoting this relative salary ratio by $S_{i}$, the relative-salary multiplier, $m_{i}^{S}$, can be written as:

$$
m_{i}^{S}=\frac{1}{S_{i}}
$$

In effect, equation 5 exempts from tax the additional salary that compensates for the higher cost of living in high-cost regions and taxes the increased purchasing power that compensates for the lower nominal salary earned in low-cost regions. Equation 5 imposes this incremental tax without directly measuring the incremental cost of living. Instead, equation 5 measures that incremental cost indirectly through the incremental salary that compensates employees for regional cost-of-living differences.

\section{B. Relative Cost-of-Living Method}

A second way to calculate the multiplier uses the relative cost of living. Denoting the statutory tax rate by $\tau$, the relative cost-of-living multiplier, $m_{i}^{C}$, is given by: ${ }^{59}$

$$
m_{i}^{C}=\frac{1}{C_{i}(1-\tau)+\tau}
$$

where $C_{i}$ is an index of the region's relative cost of living. ${ }^{60}$

The multiplier given in equation $6, m_{i}^{C}$, is not the reciprocal of the cost of living $\left(1 / C_{i}\right){ }^{61}$ Rather, it is a weighted average of the cost of living

\footnotetext{
58 That is to say, where equation 1, supra p. 992, holds.

59 The multipliers are derived in Appendix II, infra p. 1023.

60 See supra note 31.

61 The cost of living is calculated after the payment of federal income taxes. Bureau of Labor Statistics, Understanding the Consumer Price Index: Answers to Some Questions, at http://stats. bls.gov/cpi/cpi1998g.htm (last visited Jan. 11, 2003) ("[T]he CPI excludes taxes (such as income and
} 
$\left(C_{i}\right)$ and one, where the weights are the after-tax portion of income, $1-\tau$, and the portion paid in taxes, $\tau$. A weighted average is used because equilibrium does not require that gross salaries be in proportion to living costs. Instead, equilibrium requires that the after-tax portion of salaries be in proportion to living costs. ${ }^{62}$ The multiplier in equation 6 thus ensures that taxes are equal across regions when the after-tax portion of salary is in proportion to living costs. ${ }^{63}$ Thus, equations 5 and 6 each eliminate the wedge between social and private benefits that produces the inefficiency by ensuring that taxes are equal when real after-tax income is equal.

Table 3 gives the equilibrium before-tax incomes of employees in different regions with an income tax that adjusts for differences in regional living costs using equation 5 or 6 (which, in equilibrium, are the same).

TABLE 3. AdJUSTED TAX: EMPLOYEE’S INCOME

\begin{tabular}{||l|c|c|c||}
\hline & Cheap & Middling & Pricey \\
\hline \hline Before-Tax Income & $\$ 42,000$ & $\$ 50,000$ & $\$ 58,000$ \\
\hline Multiplier & 1.1905 & 1 & 0.8621 \\
\hline Effective Tax Rate & $23.81 \%$ & $20 \%$ & $17.24 \%$ \\
\hline Tax & $\$ 10,000$ & $\$ 10,000$ & $\$ 10,000$ \\
\hline $\begin{array}{l}\text { Nominal After-Tax In- } \\
\text { come }\end{array}$ & $\$ 32,000$ & $\$ 40,000$ & $\$ 48,000$ \\
\hline $\begin{array}{l}\text { Cost of Living } \\
\text { Real After-Tax In- }\end{array}$ & 0.8 & 1 & 1.2 \\
\hline \hline
\end{tabular}

Social Security taxes) not directly associated with the purchase of consumer goods and services.”). If cost-of-living figures were calculated on a before-tax instead of an after-tax basis, the reciprocal of the cost of living would be the proper multiplier.

62 The most obvious solution to the failure to adjust taxes for differences in regional living costs assessing taxes on real income by dividing nominal income by the relative cost of living — would not just eliminate the bias in favor of areas with low living costs and against areas with high living costs. If adopted, such a multiplier would also encourage employees to locate in high-cost areas and discourage them from locating in low-cost areas.

This can be made clear with an extreme example. Assume that the statutory tax rate is $50 \%$ and consider a region with a cost of living that is $50 \%$ of the national average. If the multiplier were the reciprocal of the cost of living, the effective tax rate would be $100 \%$. Thus, taxpayers living in such a region would be required to pay their entire income in federal taxes. Moreover, taxpayers living in regions with even lower living costs would be subject to effective tax rates in excess of $100 \%$ and so would be obligated to pay more than their entire income in taxes.

63 We could find only one provision in the tax code that attempts to equate nominal tax with real income. Section 912 exempts from taxation payments received by civilian employees of the U.S. government who are stationed outside of the United States when such payments are received as compensation for higher costs of living. I.R.C. § 912(2) (2000). 


\begin{tabular}{||l|l|l|l||}
\hline come & & & \\
\hline
\end{tabular}

Because the proposed modification would not adjust capital owners' taxes for differences in living costs, the return to capital is still given by Table 2B. ${ }^{64}$

It is easy to establish that the above allocation of resources is efficient. Shifting one employee from Cheap to Pricey will produce just enough revenue to compensate the employee and the Treasury. If one employee were shifted, gross revenue in Cheap would fall by $\$ 42,000$, which is divided between labor $(\$ 32,000)$ and the Treasury $(\$ 10,000)$. The shift would increase gross revenue in Pricey by $\$ 58,000$. Out of this amount, it is possible to compensate labor $(\$ 48,000)$ and the Treasury $(\$ 10,000)$ with nothing left over. As the example illustrates, the allocation of labor is efficient because the tax on salaries is the same amount $(\$ 10,000)$ in all three regions.

We can compare the efficient allocation of resources resulting from our revised income tax to the inefficient allocation that occurs with a flat tax. An income tax that efficiently adjusts for regional differences employs labor more intensively in high-cost regions and less intensively in low-cost regions. In equilibrium, salaries are $\$ 2000$ higher in Cheap $(\$ 42,000$ as opposed to $\$ 40,000)$ and $\$ 2000$ lower in Pricey $(\$ 58,000$ as opposed to $\$ 60,000$ ) with our suggested adjustment than with no adjustment. 65 Because such a salary shift can only be brought about by decreasing labor intensity in Cheap and increasing it in Pricey, it follows that labor is being used more intensively in Pricey and less intensively in Cheap with an efficient income tax than with a flat income tax. ${ }^{66}$

\section{Progressivity}

A progressive income tax may exacerbate inefficiencies due to regional cost-of-living differences. As noted earlier, even a flat tax produces an inefficient allocation of resources across regions by discouraging employers from hiring workers in high-cost regions and encouraging them to hire in low-cost regions, because the nominal tax liability is greater for employees

\footnotetext{
64 See supra p. 997.

65 Compare Table 3, row 1, supra p. 1003, with Table 2A, row 1, supra p. 996.

66 Moreover, the efficient allocation of resources in the presence of an income tax is not the same allocation that would be efficient in a no-tax world. As discussed in Part IV, supra pp. 997-1000, the allocation with a flat tax is identical to the allocation that occurs in a no-tax world, but efficiency requires that labor be used more intensively in Pricey and less intensively in Cheap than it would be in the no-tax world. Equilibrium gross salaries with an efficient income tax are \$2000 lower in Pricey ( $\$ 58,000$ as opposed to $\$ 60,000$ ) and $\$ 2000$ higher in Cheap $(\$ 42,000$ as opposed to $\$ 40,000)$ than in the no-tax world. Compare Table 3, row 1, supra p. 1003, with Table 1A, row 1, supra p. 994. Thus, compared to the no-tax world, an efficient income tax uses labor more intensively in high-cost regions and less intensively in low-cost regions.
} 
located in high-cost regions than for employees located in low-cost regions. ${ }^{67}$ This effect is exacerbated by a progressive income tax if the higher nominal income earned by taxpayers located in high-cost regions forces them into higher brackets, increasing their tax liabilities still further.

This can be illustrated by assuming that instead of a flat $20 \%$ tax, the tax rate is $15 \%$ on the first $\$ 40,000$ of income and $40 \%$ thereafter. 68 The resulting equilibrium salary levels in Cheap, Middling, and Pricey are given by Table 4.

TABle 4. Progressive TaX: EMPloyee’s InCOME

\begin{tabular}{|l|c|c|c||}
\hline & Cheap & Middling & Pricey \\
\hline \hline Before-Tax Income & $\$ 37,647$ & $\$ 50,000$ & $\$ 63,333$ \\
\hline Tax & $\$ 5647$ & $\$ 10,000$ & $\$ 15,333$ \\
\hline $\begin{array}{l}\text { Nominal After-Tax } \\
\text { Income }\end{array}$ & $\$ 32,000$ & $\$ 40,000$ & $\$ 48,000$ \\
\hline Cost of Living & 0.8 & 1 & 1.2 \\
\hline Real After-Tax Income & $\$ 40,000$ & $\$ 40,000$ & $\$ 40,000$ \\
\hline
\end{tabular}

The progressive tax schedule exacerbates the misallocation of resources across regions by further increasing the capital-labor ratio in Pricey and further reducing it in Cheap. ${ }^{69}$ Because the cost of the inefficiency can be measured by the difference in nominal taxes paid by a worker in Pricey and Cheap, that cost increases from $\$ 4000[=\$ 12,000-\$ 8000]^{70}$ to almost $\$ 10,000$ [ $=\$ 15,333-\$ 5647]$ when the flat tax is replaced with a progressive tax.

67 An efficient income tax increases the intensity with which labor is used in high-cost regions and decreases that intensity in low-cost regions (in comparison to the no-tax world) because the salary earned by each employee is not spent entirely at her regional cost of living. With an income tax, that portion paid in taxes is spent outside of the region and in a manner independent of the region's cost of living. Accordingly, since only a portion of the employee's salary (equal to one minus the tax rate) must compensate for cost of living differences, gross salaries are lower in high-cost regions and higher in low-cost regions with an efficient income tax than without an income tax. This, in turn, implies that labor is used more intensively in high-cost regions and less intensively in low-cost regions.

68 Such a tax is progressive for income levels above $\$ 40,000$ because the average tax rate increases with income. Thus, taxpayers earning $\$ 50,000$ would still pay $\$ 10,000$ in tax (20\% of their income), but taxpayers earning $\$ 40,000$ would pay only $\$ 6000$ (15\% of their income) and taxpayers earning $\$ 60,000$ would pay $\$ 14,000$ (23\% of their income).

69 That the capital-labor ratio is increased in Cheap and is reduced in Pricey follows because beforetax income is lower in Cheap and higher in Pricey (relative to Table 2A, supra p. 996).

70 See supra Table 2A, row 2, p. 996. 


\section{EARNED INCOME AND CAPITAL}

This Article has so far argued that the failure to adjust personal income tax liabilities for differences in living costs misallocates resources and has described how to adjust individual income tax liabilities to eliminate that misallocation. This Part considers whether all income should be so adjusted. It concludes that an adjustment is appropriate only when the income reflects the recipient's local cost of living (location-specific income). Roughly speaking, earned income should be adjusted for differences in living costs, but investment income should not be.

For most people, it is not feasible to live far from their place of employment. Accordingly, employers located in high-cost regions must pay high salaries because their employees incur high living expenses. The current tax system, which does not make any adjustments for differences in living costs, imposes a higher tax liability on salaries earned in high-cost areas. We have shown in Part IV that the higher tax can produce inefficiency in the interregional allocation of resources.

Not all income, however, is location-specific. Consider, for example, a cartoonist with a national audience. The cartoonist will receive the same income regardless of where he lives. There is thus no need to adjust the cartoonist's tax liability to reflect his local cost of living. Indeed, doing so would create inefficiencies by rewarding him (with lower taxes) for living in a high-cost area and by penalizing him (with higher taxes) for living in a low-cost area.

Not only cartoonists, but also many others - athletes, artists, actors, writers, inventors, import/exporters, entrepreneurs, airline pilots, newsletter publishers, consultants, etc. - earn income that is not location-specific. Their incomes are not affected by where they reside, so federal income tax considerations do not affect their decisions where to locate. Thus, efficiency requires that their incomes not be adjusted for regional differences in the cost of living. ${ }^{71}$ Of course, in some cases it can be difficult to determine the extent to which a taxpayer's income reflects the local cost of living. It can be unclear, for example, whether the publisher of a financial newsletter specializing in the analysis of stocks must live in metropolitan New York. The growth of telecommuting, moreover, is increasing the number of people who earn non-location-specific income. Nevertheless, as a rough approximation, it is probably reasonable to treat most earned income as linked to the taxpayer's place of residence.

In contrast, income from capital is not generally location-specific. Capital owners do not have to live where their capital is employed. For example, anyone within the country and many outside it can invest in the

\footnotetext{
71 There is no wedge between private and social benefits across regions because the earnings of recipients of non-location-specific income and the tax thereon are not affected by an individual's decision where to live.
} 
U.S. stock market, buy publicly traded bonds issued in the United States, or deposit money in U.S. financial institutions. The earnings on such investments do not depend on where the investor lives, and thus a tax on the return does not need to be adjusted for regional cost-of-living differences. ${ }^{72}$ Indeed, if it were adjusted, it would provide a tax subsidy for investors who live in high-cost regions. It would also encourage investment by those living in high-cost regions and discourage investment by persons living in low-cost regions. ${ }^{73}$ Therefore, the existing tax system's practice of ignoring cost-of-living differences is the efficient method of taxing income from capital. ${ }^{74}$

\section{CONSUMPTION AMENITIES}

So far, we have assumed that the value of each region's consumption amenities is the same. We have assumed that individuals place equal value on proximity to California surf, Arizona sun, New Orleans jazz, Rocky Mountain skiing, Chicago theater, Southern hospitality, New England foliage, New York museums, and small-town America's low crime rate. This Part considers how the analysis changes when it takes into account the differing values of consumption amenities across regions. ${ }^{75}$

When differences in amenities are excluded from the analysis, salary differences will reflect differences in living costs in the manner stated by equation $1 .{ }^{76}$ That equation states that, in equilibrium, real after-tax income is constant across regions. Thus, differences in salaries offset differences in living costs. When allowance is made for differences in the level of amenities, the relationship between salaries and the cost of living is no longer as simple. Rather, equilibrium among individuals requires that the

\footnotetext{
72 This can be seen from Table 2B, row 2, supra p. 997. Both the tax paid and the after-tax return are equal across the three regions. Thus, shifting one unit of capital across regions will produce just enough revenue to compensate the capital owners and the Treasury.

73 Some of the income from capital might be viewed as location-specific. Many capital owners invest locally and play an active role in the business. Nonetheless, the tax on the income from capital should not be adjusted for regional differences in living costs. Capital can always be invested in a national (or even international) market. Thus, at most, only the excess return a taxpayer earns over what she would earn by investing in the national market should be adjusted for differences in regional living costs. This portion of the return is arguably a return to location-specific labor, not capital, and market forces would tend to eliminate such regional differences. Therefore, because market pressures tend to eliminate such inframarginal returns, as a first approximation, all income from capital should be taxed at the national rate. This logic also would apply to income subject to a corporate-level income tax. Because the ultimate recipients, the shareholders, do not necessarily live near the corporation's offices and plants, and because they could invest in other corporations and get a similar return, corporate income should be taxed at the national rate.

74 There is no wedge between private and social benefits across regions because the return on investment and the tax thereon are both independent of where the taxpayer chooses to invest.

75 Regions also might differ in production amenities. For the rest of this Part, however, the term "amenities" refers only to consumption amenities.

76 See supra p. 992
} 
sum of real after-tax income and the value of a region's amenities (expressed here as the difference from the national average) be constant across regions.

$$
\frac{{\text { After-Tax } \text { Income }_{i}}_{\text {Cost of Living }_{i}}}{\text { Amenities }_{i}}=K^{\prime} \text { for all regions } i \text {, }
$$

where $K^{\prime}$ is an occupation-specific constant.

With consumption amenities, there is no longer a simple relationship between a worker's after-tax income and the regional cost of living. For example, a region that pays relatively low salaries might do so either because living costs are low or because local amenities are attractive. Similarly, a region that pays high salaries might do so either because living costs are high or because local amenities are unattractive. Expressed slightly differently, a high level of amenities might be reflected in low salaries, a high cost of living, or some combination of both. ${ }^{77}$

\section{A. The Tax Treatment of Amenities and the Allocation of Resources}

Consider three regions - Gloomy, Normal, and Sunny - with different amenity levels. Gloomy has less than the national average level of amenities, Normal has the average, and Sunny has more than the average. Assume that for taxpayers with real incomes of $\$ 50,000$, the amenities in Gloomy are worth $\$ 2000$ less than the national average and those in Sunny are worth $\$ 2000$ more. ${ }^{78}$

This Part will consider two polar cases. In the first, differences in amenities will be reflected entirely in salaries; in the second, differences in amenities will be reflected entirely in living costs. ${ }^{79}$

1. Amenities Fully Reflected in Salaries. - Initially, assume that all three regions have the national average cost of living. In the absence of an income tax, salaries in Gloomy will be $\$ 2000$ above those in Normal, which, in turn, will be $\$ 2000$ above those in Sunny. Equilibrium salaries and amenity levels are given in Table 5A below.

Again, we assume that the return to capital is $\$ 22,500$ in each region, as illustrated in Table 5B below. ${ }^{80}$

\footnotetext{
77 See Jennifer Roback, Wages, Rents, and the Quality of Life, 90 J. POL. ECON. 1257, 1262 (1982).

78 In general, the dollar value of amenities will increase as a taxpayer's income rises. This is true even for amenities that may provide the same increase in welfare for all individuals. A beautiful view, for example, may provide equal enjoyment to individuals of all incomes. A low-income individual would probably be willing to pay little for that view because she has other pressing needs, such as food and shelter. A high-income individual, however, can afford to spend a substantial sum on a good view and still have ample funds remaining to satisfy her other needs.

79 The theoretical and empirical literature suggests that amenities are capitalized into both living costs and salaries. See, e.g., Gyourko et al., supra note 27, at 1420.

80 As explained above, supra p. 994, the equilibrium return to capital is the same across regions and is unaffected by salaries, costs of living, or regional amenities.
} 
TABle 5A. No TAX AND AmENitiES REFLECTED IN SALARY: EMPLOYEE’S INCOME AND AMENITIES

\begin{tabular}{|l|c|c|c||}
\hline & Gloomy & Normal & Sunny \\
\hline \hline Income & $\$ 52,000$ & $\$ 50,000$ & $\$ 48,000$ \\
\hline Amenities & $(\$ 2000)$ & $\$ 0$ & $\$ 2000$ \\
\hline $\begin{array}{l}\text { Income plus } \\
\text { Amenities }\end{array}$ & $\$ 50,000$ & $\$ 50,000$ & $\$ 50,000$ \\
\hline
\end{tabular}

TABLE 5B. No TAX AND AMENITIES REFLECTED IN SALARY: RETURN TO CAPITAL

\begin{tabular}{|l|c|c|c|}
\hline & Gloomy & Normal & Sunny \\
\hline Return to Capital & $\$ 22,500$ & $\$ 22,500$ & $\$ 22,500$ \\
\hline
\end{tabular}

The equilibrium salaries and amenity levels for employees in the presence of a flat $20 \%$ income tax are given in Table $6 \mathrm{~A}$.

TABLE 6A. 20\% UNADJUSTED TAX AND AMENITIES REFLECTED IN SALARY: EMPLOYEE'S INCOME AND AMENITIES

\begin{tabular}{|l|c|c|c||}
\hline & Gloomy & Normal & Sunny \\
\hline \hline Before-Tax Income & $\$ 52,500$ & $\$ 50,000$ & $\$ 47,500$ \\
\hline Tax (20\%) & $\$ 10,500$ & $\$ 10,000$ & $\$ 9500$ \\
\hline After-Tax Income & $\$ 42,000$ & $\$ 40,000$ & $\$ 38,000$ \\
\hline Amenities & $(\$ 2000)$ & $\$ 0$ & $\$ 2000$ \\
\hline $\begin{array}{l}\text { After-Tax Income plus } \\
\text { Amenities }\end{array}$ & $\$ 40,000$ & $\$ 40,000$ & $\$ 40,000$ \\
\hline
\end{tabular}

The corresponding return to capital is shown in Table 6B. Because only location-specific income reflects amenity and living-cost differences, the income from capital is the same across regions and is not adjusted. Accordingly, Table 6B describes the return to capital in the presence of a flat $20 \%$ income tax, regardless of how the tax is adjusted for regional differences. 
TABLE 6B. 20\% UNADJUSTED TAX AND AMENITIES REFLECTED IN SALARY: RETURN TO CAPITAL

\begin{tabular}{||l|c|c|c||}
\hline & Gloomy & Normal & Sunny \\
\hline \hline Taxable Income & $\$ 22,500$ & $\$ 22,500$ & $\$ 22,500$ \\
\hline Tax (20\%) & $\$ 4500$ & $\$ 4500$ & $\$ 4500$ \\
\hline Return to Capital & $\$ 18,000$ & $\$ 18,000$ & $\$ 18,000$ \\
\hline
\end{tabular}

It is easy to see that the equilibrium described by Tables $6 \mathrm{~A}$ and $6 \mathrm{~B}$ is inefficient. By shifting one employee from Sunny to Gloomy, it is possible to compensate the employee and the Treasury and still have \$1000 left over. $^{81}$ This misallocation occurs because the additional \$5000 of salary in Gloomy is taxed (\$1000), whereas the greater value of amenities in Sunny (\$4000) is not. In effect, when salaries reflect amenity differences, a flat tax encourages taxpayers to locate in high-amenity/low-salary regions and discourages them from locating in low-amenity/high-salary regions, thus misallocating resources. ${ }^{82}$ This misallocation is independent of the misallocation that occurs when taxpayers are encouraged to locate in low-cost regions and discouraged from locating in high-cost regions.

2. Amenities Fully Reflected in Cost of Living. - In the previous subsection, any differences in amenities were assumed to be reflected in salaries. This subsection makes the opposite assumption: any differences in amenities are reflected in living costs. In the absence of an income tax, salaries are equal across regions, but living costs are lower in Gloomy and higher in Sunny to reflect the difference in amenities. ${ }^{83}$ Table 7 illustrates this scenario. ${ }^{84}$

TABle 7. No TAX AND Amenities Reflected in LiVing Costs: EMPLOYEE’S INCOME AND AMENITIES

\begin{tabular}{|l|c|c|c|}
\hline & Gloomy & Normal & Sunny \\
\hline
\end{tabular}

81 Removing one employee from Sunny will cost the employee $\$ 38,000$ in after-tax earnings and $\$ 4000$ in lost amenities. It will also cost the Treasury $\$ 9500$. Adding one employee to Gloomy will provide the employee with $\$ 42,000$ in after-tax earnings. The additional $\$ 4000$ in salary exactly compensates the employee for the lost amenities. After the Treasury receives $\$ 9500$ to compensate for its lost revenue, there remains $\$ 1000$ to distribute.

82 Another way of thinking about this tax is that it drives a wedge between social and private benefits across regions. The sum of after-tax income and amenities is equal across regions, but taxes are not. See supra Table 6A, rows 2 and 5, supra p. 1009.

83 Rounded to two decimal places, the relative cost of living in Gloomy is 0.96, and the relative cost of living in Sunny is 1.04 .

84 The corresponding return to capital is shown in Table 5B, supra p. 1009. 


\begin{tabular}{||l|c|c|c||}
\hline Nominal Income & $\$ 50,000$ & $\$ 50,000$ & $\$ 50,000$ \\
\hline Cost of Living & 0.96 & 1 & 1.04 \\
\hline Real Income & $\$ 52,000$ & $\$ 50,000$ & $\$ 48,000$ \\
\hline Amenities & $(\$ 2000)$ & $\$ 0$ & $\$ 2000$ \\
\hline $\begin{array}{l}\text { Real Income plus } \\
\text { Amenities }\end{array}$ & $\$ 50,000$ & $\$ 50,000$ & $\$ 50,000$ \\
\hline
\end{tabular}

After an income tax is imposed, salaries remain equal across regions. However, the cost of living falls in Gloomy and rises in Sunny. ${ }^{85}$ Table 8 illustrates the before- and after-tax incomes of employees and the changed costs of living. ${ }^{86}$

TABLE 8. 20\% UNADJUSTED TAX AND AMENITIES REFLECTED IN LIVING COSTS: EMPLOYEE’S INCOME AND AMENITIES

\begin{tabular}{||l|c|c|c||}
\hline & Gloomy & Normal & Sunny \\
\hline \hline Before-Tax Income & $\$ 50,000$ & $\$ 50,000$ & $\$ 50,000$ \\
\hline Tax (20\%) & $\$ 10,000$ & $\$ 10,000$ & $\$ 10,000$ \\
\hline $\begin{array}{l}\text { Nominal After-Tax } \\
\text { Income }\end{array}$ & $\$ 40,000$ & $\$ 40,000$ & $\$ 40,000$ \\
\hline Cost of Living & 0.95 & 1 & 1.05 \\
\hline $\begin{array}{l}\text { Real After-Tax } \\
\text { Income }\end{array}$ & $\$ 42,000$ & $\$ 40,000$ & $\$ 38,000$ \\
\hline \begin{tabular}{l} 
Amenities \\
\hline $\begin{array}{l}\text { Real After-Tax } \\
\text { Income plus Amenities }\end{array}$
\end{tabular} & $\$ 40,000$ & $\$ 40,000$ & $\$ 40,000$ \\
\hline
\end{tabular}

When the differences in living costs fully reflect the differential value of amenities, the allocation of resources remains efficient after the introduction of a flat tax. ${ }^{87}$ As Table 8 shows, it is not possible to increase

85 More precisely, the relative cost of living in Gloomy falls 0.01 , from 0.96 to 0.95 ; the relative cost of living in Sunny rises 0.01 , from 1.04 to 1.05 .

86 The corresponding return to capital, which remains the same as it was in our first scenario, is illustrated in Table 6B, supra p. 1010.

87 In other words, the tax does not drive a wedge between private and social benefits. When the nominal tax is equal across regions, so is the sum of real after-tax income and amenities. This is true 
anyone's welfare by shifting resources without reducing either someone else's welfare or the government's tax revenues. ${ }^{88}$ The allocation remains efficient because, unlike in our prior scenario, employees pay the same tax $(\$ 10,000)$ across regions. In effect, individuals pay for increased amenities through higher living costs.

The above analysis suggests that the existing income tax's treatment of consumption amenities is sometimes efficient and sometimes inefficient. To the extent that the difference in amenities is reflected in living costs, the equilibrium allocation of resources is efficient; however, to the extent that the difference is reflected in salaries, that allocation is not efficient. ${ }^{89}$ The logic is simple. If the difference is reflected in living costs, salaries and thus taxes will be the same across regions, so there is no tax-induced incentive to prefer one region over another. Conversely, if the difference is reflected in salaries, salaries and thus taxes will be higher in low-amenity regions than in high-amenity regions. The difference in after-tax income across regions will not offset the difference in levels of amenities, creating a tax-induced bias in favor of regions with high amenities. ${ }^{90}$ This understanding requires us to modify our previous conclusions regarding differences in cost of living. Because differences in the cost of living that reflect differences in amenities do not yield an inefficient allocation of resources, not all cost-of-living differences warrant a tax adjustment.

\section{B. Adjusting Taxes for Differences in Amenities}

Earlier, we described two multipliers ${ }^{91}$ — one using relative salaries (equation 5) and the other using relative living costs (equation 6) - that eliminate tax-induced inefficiency when living costs vary across regions but the value of amenities does not. Both multipliers equalized nominal tax liabilities across regions, thereby ensuring that taxes did not affect the decisions where to live and invest. In this section, we assess whether those multipliers will lead to an efficient allocation of resources when the level of amenities differs across regions.

The multiplier derived from cost-of-living differences (equation 6) does not lead to such an allocation, for two reasons. First, when salaries

because before-tax income is equal across regions. The efficient allocation is the same with or without an income tax.

88 For example, shifting one employee from Sunny to Gloomy will increase her real after-tax income by $\$ 4000$ and reduce the value of her amenities by $\$ 4000$. Thus, she is indifferent to the move. The Treasury is also indifferent because its tax revenue is exactly $\$ 10,000$ both before and after the shift.

89 In general, differences in consumption amenities will be reflected in salaries when employees located in high-amenity regions are less productive than employees located in low-amenity regions; they will be reflected in living costs when employees located in high-amenity areas are just as productive. See Gyourko et al., supra note 27, at 1420.

90 Progressivity in the rate schedule will reinforce this bias.

91 See supra pp. 1001-04. 
fully reflect differences in amenities, equation 6 does not eliminate the inefficiency. In that situation, the multiplier makes no adjustment because the cost of living is the same across regions. As described above, an adjustment is required because nominal income, and hence taxes, are higher in low-amenity areas and lower in high-amenity regions, ${ }^{92}$ thus encouraging employees to consume more amenities rather than earn higher salaries. Second, when living costs fully reflect differences in amenities, the multiplier creates an inefficiency. This occurs because equation 6 makes an adjustment when the allocation of resources across regions is already efficient, since nominal taxes are equal across regions. ${ }^{93}$

The multiplier derived from relative salaries (equation 5), in contrast, efficiently allocates resources when amenities differ among regions. When living costs reflect the differential value of local amenities, no adjustment is needed because taxes are equal across regions, ${ }^{94}$ and equation 5 produces no adjustment because salaries are equal across regions. ${ }^{95}$ When differences in amenities are reflected in salaries, equation 5 is the efficiencyproducing adjustment, as shown in Table $9 .{ }^{96}$

The equilibrium described by Table 9 is efficient because there is no way to shift employees across regions to produce a gain after compensating employees, owners of capital, and the Treasury. That is because, despite different nominal (and real) monetary incomes, taxes are equal across regions $^{97}$ (as are, of course, returns to capital and the sum of after-tax income and amenities). Since differences in monetary incomes reflect differences in the value of each region's amenities, the multiplier, in effect, taxes the differential value of regional amenities. ${ }^{98}$ Thus, when we use the relative salary multiplier, the resulting equilibrium is efficient.

TABle 9. 20\% AdJUSTED TAX AND AMENITIES REFLECTED IN SALARY: EMPLOYEE'S INCOME AND AMENITIES

\begin{tabular}{||l|c|c|c||}
\hline & Gloomy & Normal & Sunny \\
\hline \hline Before-Tax Income & $\$ 52,000$ & $\$ 50,000$ & $\$ 48,000$ \\
\hline
\end{tabular}

\footnotetext{
92 See supra Table 6A, rows 1-2, supra p. 1009.

93 See supra Table 8, row 2, supra p. 1011.

94 See id.

95 See id. row 1.

96 Once again, Table 6B gives the corresponding figures for capital holders.

97 See supra Table 9, row 5, supra p. 1014.

98 As when living costs fully reflect amenities, the efficient allocation of resources is the same with a flat tax as with no tax. This is true because $\$ 1$ of revenue has the same purchasing power for taxpayers and the government. This assumes, however, that differences in living costs only reflect amenities. If there are cost-of-living differences unrelated to amenities, the purchasing power of $\$ 1$ is not the same for the taxpayer and the government, so the efficient allocation of resources with a tax differs from that without a tax.
} 


\begin{tabular}{|l|c|c|c||}
\hline Cost of Living & 1 & 1 & 1 \\
\hline $\begin{array}{l}\text { Relative-Salary } \\
\text { Multiplier }\end{array}$ & 0.962 & 1 & 1.042 \\
\hline $\begin{array}{l}\text { Adjusted Taxable In- } \\
\text { come99 }\end{array}$ & $\$ 50,000$ & $\$ 50,000$ & $\$ 50,000$ \\
\hline Tax (20\%) & $\$ 10,000$ & $\$ 10,000$ & $\$ 10,000$ \\
\hline After-Tax Income & $\$ 42,000$ & $\$ 40,000$ & $\$ 38,000$ \\
\hline Amenities & $(\$ 2000)$ & $\$ 0$ & $\$ 2000$ \\
\hline $\begin{array}{l}\text { After-Tax Income plus } \\
\text { Amenities }\end{array}$ & $\$ 40,000$ & $\$ 40,000$ & $\$ 40,000$ \\
\hline
\end{tabular}

In an actual economy of any substantial size, there will likely be regional differences in both living costs and amenities. ${ }^{100}$ As shown in this Part, equation 5 - the reciprocal of the region's relative salary level efficiently adjusts both for differences in regional living costs and for differences in regional amenities. This relative-salary multiplier works by ensuring that the tax system imposes the same nominal tax on taxpayers with the same standard of living. ${ }^{101}$

\section{Limits on the Ability To Adjust Salaries for Amenities}

The income tax, by taxing the differential value of regional amenities has the potential to reduce the misallocation of resources across regions. There are, however, limitations on the ability of the proposed tax adjustment to capture the value of local amenities. Three limitations are discussed in this section.

The first limitation is that the tax imposed on the differential value of amenities is accurate only at the margin. Individuals who value local

99 Adjusted taxable income equals the product of before-tax income (row 1) and the relative-salary multiplier (row 3).

100 See supra pp. 990, 1007-08.

101 The relative salary multiplier also eliminates another distortion created by an income tax that does not adjust for differences in regional amenities. Such a tax encourages the development of new consumption amenities that are reflected in lower salaries and discourages the development of new consumption amenities that are reflected in living costs (that is to say, rents and land prices) and new production amenities that increase salaries. The first type of investment is encouraged because benefits from new consumption amenities that are reflected in lower salaries reduce taxes, whereas investments of the last two types are discouraged because benefits from new consumption amenities that increase rents and land prices increase taxes, as do new production amenities that raise salaries. By including the relative value of regional amenities in the tax base, an income tax that adjusts for differences in regional amenity levels can eliminate this distortion by subjecting the benefits from all three types of investment to tax. 
amenities more than the marginal resident does are taxed not on their personal value, but only on the value of the amenities to the marginal resident. For example, residents of Big Sur who would not move even if their salaries were cut in half are not taxed on the full value they place on their perch overlooking the Pacific Ocean. Because they value living in Big Sur more than the marginal resident does, they do not affect the difference between salaries in the region and elsewhere. Suppose, for example, that the marginal resident would be indifferent between earning \$50,000 in Big Sur and earning $\$ 10,000$ more in a region with average amenities. ${ }^{102}$ Residents of Big Sur who would be willing to accept a \$25,000 reduction in income to live there will pay tax on only $\$ 10,000$ of amenities, the value of living in Big Sur to the marginal resident.

That result, however, is not unique to the enjoyment of regional amenities. Precisely the same phenomenon occurs when individuals purchase goods for cash. The most devoted fan of the Metropolitan Opera is "taxed" only on the actual amount he paid for the tickets, not on the much higher amount he would have been willing to pay. Despite this, taxing the inframarginal value of amenities is not necessary to ensure the efficient allocation of resources. Inframarginal values do not affect the equilibrium wage, so they will not affect where individuals at the margin choose to live. ${ }^{103}$

The second limitation is that the tax will be accurate only once equilibrium is established. When the economy is not in equilibrium and people are relocating to take advantage of differences in living standards, the tax will not capture the value of amenities to the marginal resident. For entrylevel and other highly fungible jobs, equilibrium might be established relatively quickly, in which case any resulting error is likely to be small. For positions that require in-depth local knowledge or local goodwill, however,

102 Such a marginal resident would not leave Big Sur if the salary differential was $\$ 10,000$ or less, but would leave if the differential was greater than $\$ 10,000$.

103 To avoid biasing the decision whether to earn location-specific or non-location-specific income, efficiency requires taxing recipients of non-location-specific income on the value of amenities reflected in regional salaries.

The efficiency-producing multiplier for those who earn non-location-specific income separates the portion of the difference in relative salaries that compensates for living-cost differences from the portion that compensates for amenity differences. Only the latter, the salary difference that compensates for amenity differences, is properly included in the multiplier. The multiplier, $m_{i}^{A}$, is calculated as follows:

$$
m_{i}^{A}=\frac{C_{i}(1-\tau)+\tau}{S_{i}},
$$

where $S_{i}$ is the relative salary, $C_{i}$ is the cost of living, and $\tau$ is the tax rate. The same multiplier, which is the ratio of equations 5 and 6 , supra p. 1002, can be rewritten as:

$$
m_{i}^{A}=\frac{m_{i}^{S}}{m_{i}^{C}} .
$$


it could take years to establish equilibrium, increasing the potential for errors. ${ }^{104}$

The third limitation is that it is impossible to adjust for differences in some regional amenities but not for others. For example, it is impossible to adjust for regional differences in schools, but not for hours worked. If the income tax is adjusted using the relative salary multiplier, then the implicit market value of all regional differences is captured by the tax system. ${ }^{105}$

\section{Refining the Tax Base}

Subjecting the differential value of amenities to taxation would refine the personal income tax base. Under current law, the tax base is roughly the cash income of taxpayers plus the market value of noncash goods and services received. ${ }^{106}$ Excluded from the base are amenities, working conditions, prestige, job safety and security, and many other desirable and undesirable characteristics of work and life. Commentators have debated for years the propriety and feasibility of taxing such attributes. ${ }^{107}$ This Article has shown that it is possible to tax the differential value of regional amenities without directly measuring their value. If equivalent jobs can be identified across regions, then the differential value of amenities can be included in the tax base by imposing the same nominal tax liability on taxpayers with equivalent jobs in different regions regardless of actual income. ${ }^{108}$

The idea is that the differential value of amenities can be measured indirectly by using the implicit prices that people pay through different salaries. ${ }^{109}$ The difficulty with this method is identifying equivalent jobs in

104 However, the efficiency cost from any such errors is likely to be small because movement is expensive.

105 It might be possible to adjust for only selected amenities by using econometric techniques to estimate the values of selected amenities, but that matter is beyond the scope of this discussion.

106 Barter is included in income. Fringe benefits are also included, unless they are explicitly excluded by statute.

107 The issue is usually described as mixing business and personal expenditures, and the debate is usually framed around what portion, if any, of the cost of these mixed expenditures should be deductible. See generally Thomas D. Griffith, Efficient Taxation of Mixed Personal and Business Expenses, 41 UCLA L. Rev. 1769 (1994); Daniel I. Halperin, Business Deduction for Personal Living Expenses: A Uniform Approach to an Unsolved Problem, 122 U. PA. L. REV. 859 (1974); William A. Klein, The Deductibility of Transportation Expenses of a Combination Business and Pleasure Trip - A Conceptual Analysis, 18 STAN. L. REV. 1099 (1966); William A. Klein, Income Taxation and Commuting Expenses: Tax Policy and the Need for Nonsimplistic Analysis of "Simple" Problems, 54 CORNELL L. REV. 871 (1969).

108 The value of amenities across regions might also differ across job categories. For example, lawyers, accountants, and their secretaries might all place different values on regional amenities. These differences will be reflected in the market by salary differences across regions.

109 This indirect measurement is the idea behind the compensating differential model used regularly in regional economics. The fundamental assumption is that workers and capital owners are both in equilibrium, so regional differences in wages and rents are compensated for elsewhere through amenities or government spending and taxing policy. Gyourko et al., supra note 27, at 1416. Over the last twenty years, a large body of literature has used empirical techniques to estimate the value of the amenities or government spending under the assumption that the market is in equilibrium. For surveys 
different regions. Jobs are equivalent if individuals who accept the job in one region could obtain the job in another region, and vice versa. The possibility of movement in both directions means that market forces will tend to push the two jobs toward providing employees with the same standard of living. Collecting the same amount of tax from taxpayers who earn different salaries from jobs that differ only in their locations permits the differential value of regional amenities to be taxed. ${ }^{110}$

Interestingly, including amenities (and other fringe or incidental benefits) in the tax base would neither increase the aggregate dollar value of the base nor raise tax revenue. ${ }^{111}$ That is because only the differential value of amenities is included in the tax base. By definition, the average of the differentials is zero, so neither the tax base nor the resulting tax revenue increases. As a result, aggregate tax liability is reallocated across regions. This reallocation could be expected to improve efficiency by eliminating the tax-induced bias against earning wages and in favor of receiving noncash compensation (such as prestige, leisure, and luxurious working conditions).

\section{SHOUlD TAXES BE ADJUSTED FOR DIFFERENCES IN LIVING COSTS AND AMENITIES?}

It is common in the tax literature to say that a tax system should be fair, feasible, and efficient. ${ }^{112}$ Earlier parts of this Article have focused on efficiency concerns. This Part will briefly consider issues of fairness and feasibility.

\section{A. Fairness}

The mobility of persons largely eliminates fairness arguments based on the differential taxation of persons residing in different regions. Such movement tends to eliminate differences in living standards (the sum of after-tax real income plus amenities) between regions for individuals with similar skills and drive. Thus, in equilibrium, the most common fairness

of that literature, see Timothy J. Bartik \& V. Kerry Smith, Urban Amenities and Public Policy, in HANDBOOK OF REgIONAL AND URBAN ECONOMICS 1207 (Edwin S. Mills ed., 1987) (for surveys through 1987); and Gyourko et al., supra note 27 (for surveys since 1987). The method described in this Article would use those same techniques to assess tax liabilities. However, instead of using those techniques to estimate the price implicitly paid, the method uses the assumption of equilibrium to equate jobs across regions so that their occupants can be assessed the same tax liability.

110 If there were other systematic differences across regions, such as in working conditions, these differences would be taxed as well.

111 Of course, if the increased efficiency from including amenities in the tax base translates into faster economic growth, then the inclusion of amenities will increase the tax base.

112 E.g., John B. Shoven \& Paul Taubman, Saving, Capital Income, and Taxation, in THE ECONOMICS Of TAXATION 203, 203-04 (Henry J. Aaron \& Michael J. Boskin eds., 1980). 
argument — that similarly-situated taxpayers are taxed differently — is not valid. ${ }^{113}$

The U.S. economy has long had a tax system that does not adjust individuals' tax liabilities for differences in regional living costs and amenities. Thus, any incremental subsidy or tax resulting from that system has likely already been competed away and capitalized into wages and home prices. Consequently, adjusting taxes for differences in regional living costs and amenities would produce windfall losses for individuals living in areas where taxes would increase and windfall gains for individuals living in areas where taxes would fall.

The magnitude of these windfalls, however, can be reduced by implementing the changes slowly. The longer the transition period, the smaller the windfalls. Of course, the longer the transition period, the smaller the overall efficiency gains. Nonetheless, the ability to limit windfalls blunts fairness arguments against implementing the adjustment. ${ }^{114}$

\section{B. Feasibility}

There are several practical problems with developing a workable tax system that adjusts for differences in regional living costs and amenities. ${ }^{115}$ This section first describes problems in calculating relative living costs, then problems in calculating relative salaries, and finally problems that apply to both. ${ }^{116}$

1. Problems in Calculating Relative Living Costs. - Although reasonably good data is readily available on the cost of goods and services in different regions, it is far from easy to construct a measure of differential living costs. ${ }^{117}$ A report by the General Accounting Office described more than a dozen different methodologies for comparing living costs in differ-

113 That argument is only valid during the transition, before the market has established a new equilibrium.

114 A simple way of phasing in the transition slowly is to create a transitional multiplier equal to a weighted average of one and the regional multiplier. For example, the weight assigned to the usual multiplier could increase by one-tenth each year, starting at one-tenth in the first year and reaching one (tentenths) in the tenth year. The corresponding weight assigned to one would decrease by one-tenth each year, starting at nine-tenths and reaching zero in the tenth year.

115 Incorporating progressivity into the tax schedule, however, is not among these problems. To be taken seriously, the proposal to adjust taxes for differences in regional living costs and amenities must work with a progressive rate schedule. (For not only is the current rate schedule progressive, but so are all versions of the flat tax that have been proposed in Congress.) Fortunately, the adjustment is simple when the multiplier uses relative salaries ( $m_{i}^{S}$, equation 5 , supra p. 1002). In that case, the beginning and end points of each bracket are multiplied by the region's relative salary, and the bracket's tax rate is divided by the relative salary level. (That is to say, the beginning and end points of each bracket are divided by the quantity in equation 5 and the tax rate is multiplied by the quantity in equation 5 .)

116 Making the proper adjustment for all taxpayers requires information on both relative living costs and relative salaries. See equation 5, supra p. 1002, and the first equation in note 103.

117 The problem of comparing a vector of prices at different times or for different places is well known in economics: it is called the price-index problem. That problem is discussed briefly in Kaplow, supra note 7 , at $188-89$. 
ent regions. ${ }^{118}$ Moreover, the cost of living is usually measured by the cost of purchasing a specific basket of goods and services. Because the consumption basket typically changes with income, the relative cost of living for consumers with different incomes can differ substantially across regions. ${ }^{119}$ Thus, it might be necessary to have different cost of living measures for different income levels. ${ }^{120}$

2. Problems in Calculating Relative Salaries. - To compare salaries in different regions, we need data for a wide variety of occupations and salary levels. The quality of that data is likely to be far less reliable than data on the cost of goods and services. Apples must be compared to apples. Such comparisons might be difficult for many occupations because individuals with the same title and even the same number of years of experience might have very different skills and levels of proficiency. Moreover, those differences might vary systematically from region to region. ${ }^{121}$ Furthermore, regional differences in salaries might be attributable to other differences that vary systematically, such as work effort. In that case, salary would be undertaxed in regions where long work hours are common and overtaxed where work hours are shorter.

3. Problems in Calculating Both Variables. - Both the cost-of-living and the relative salary level adjustments require dividing the country into different regions. The usefulness of the data increases as the regions are defined more narrowly. However, the more narrowly the regions are defined, the more burdensome the data requirements become.

Another difficult problem is determining what portion of a taxpayer's income should be adjusted for differences in living costs. Is the division between earned and capital income a reasonable basis for estimating the portion of a taxpayer's income that is location-specific? Assuming that the labor-capital division is sound, can earned income be accurately distinguished from capital income? ${ }^{122}$

118 GEN. ACCOUNTING OFFICE, supra note 35, at 7 tbl.1.

119 This problem is likely to be especially acute for very high earners who probably spend a smaller portion of their income at the regional cost of living and a larger portion of their income on luxuries that are sold on the international market.

120 For example, ACCRA claims to calculate the cost of living for the top quintile of professionals and executives. ACCRA COST OF LIVING INDEX, supra note 18, at i. The problem of calculating multiple cost-of-living measures would not occur if equation 5, supra p. 1002, were used as the multiplier because relative salaries would take into account the earner's likely consumption basket.

121 Systematic regional variation can create interesting incentive problems. For tax purposes, it would be desirable to calculate the multiplier by comparison with lower-compensated, not highercompensated, individuals. However, for business and prestige purposes, it is frequently desirable to make comparisons with higher-compensated individuals.

122 For a critical discussion of previous attempts in the tax law to distinguish earned and unearned income, see Michael Asimow, Section 1348: The Death of Mickey Mouse?, 58 CAL. L. REV. 801 (1970). The ordinary return on capital can be separated from earned income and the net present value of an investment. However, the total return on capital (the ordinary return plus the net present value) cannot easily be separated from earned income and taxed at a different effective rate. See Michael S. Knoll, Designing A Hybrid Income-Consumption Tax, 41 UCLA L. REV. 1791, 1820-21 (1994) (arguing 


\section{CONCLUSION}

Taxpayers pay tax on their nominal income without regard to their regional cost of living or the value of their regional amenities. Although the income tax's failure to account for such differences has been criticized as unfair - because residents of high-cost and low-amenity regions pay higher taxes than residents of low-cost and high-amenity regions - that argument is unpersuasive because migration tends to eliminate regional differences in living standards. However, failure to adjust for cost-ofliving differences is likely to misallocate resources across regions.

There are two central misallocations. First, the current tax system discourages taxpayers from settling in high-cost regions where the high cost of living is matched by high earnings. Second, the tax system discourages taxpayers from settling in low-amenity regions where the lower value of amenities is reflected in higher salaries rather than lower living costs. ${ }^{123}$ Taxpayers are discouraged from settling in both types of regions because their nominal taxes will be higher. ${ }^{124}$

Both misallocations can be eliminated by adjusting each taxpayer's earned income (but not her unearned income) using the relative-salary multiplier, which is the reciprocal of the region's relative salary level. Applying the multiplier effectively taxes each resident on the marginal value (as determined by the market) of the region's relative cost of living and its amenities, which would otherwise escape tax. That multiplier thus imposes the same nominal tax on each resident without regard to her location, thereby eliminating the tax-driven incentive for individuals to settle in what, under the current tax system, are low-tax regions.

In sum, there is a strong efficiency argument in favor of adjusting taxes using the relative-salary multiplier. There are also no strong fairness arguments against making such adjustments. There are, however, difficult implementation issues. These problems are not necessarily insurmountable, but they warrant serious attention.

that the cash-flow method of implementing a consumption tax is practicable, whereas the yieldexemption method is not, because the former subjects the net present value (NPV) of an investment to tax at ordinary income rates, whereas the latter exempts the NPV from tax).

123 In effect, the residents of such high-amenity regions purchase their greater amenities with beforetax dollars through lower salaries.

124 Taxpayers are neither encouraged nor discouraged from living in high-amenity regions in which the differential value of amenities is reflected in higher living costs (not lower salaries). The reason is that these amenities are purchased with after-tax dollars through higher living costs. 


\section{APPENDICES}

Appendix I. The Relative Cost OF LIVING IN VARIOUS U.S. CitIES AS OF MID-2002

\begin{tabular}{|c|c|}
\hline $\begin{array}{l}\text { Approximate } \\
\text { Relative Cost of Liv- } \\
\text { ing }\end{array}$ & $\begin{array}{l}\text { Representative } \\
\text { Cities }\end{array}$ \\
\hline 0.85 & Kingsport \\
\hline 0.90 & $\begin{array}{l}\text { Albany (Ga.) } \\
\text { Jackson } \\
\text { Memphis } \\
\text { Nashville } \\
\text { Oklahoma City } \\
\text { Roanoke }\end{array}$ \\
\hline 0.95 & $\begin{array}{c}\text { Yuma } \\
\text { Champaign-Urbana } \\
\text { Jacksonville } \\
\text { Cincinnati } \\
\text { Norfolk }\end{array}$ \\
\hline 1.00 & $\begin{array}{c}\text { Tuscaloosa } \\
\text { Orlando } \\
\text { Atlanta } \\
\text { New Orleans } \\
\text { Buffalo } \\
\text { Raleigh } \\
\text { Charleston } \\
\text { Olympia }\end{array}$ \\
\hline 1.05 & $\begin{array}{c}\text { Flagstaff } \\
\text { Denver } \\
\text { West Palm Beach } \\
\text { Minneapolis-St. Paul } \\
\text { Cleveland } \\
\text { Portland (Or.) }\end{array}$ \\
\hline 1.10 & $\begin{array}{c}\text { Reno } \\
\text { Santa Fe } \\
\text { Chapel Hill } \\
\text { Charlottesville }\end{array}$ \\
\hline 1.20 & Anchorage \\
\hline
\end{tabular}




\begin{tabular}{|c|c|}
\hline & $\begin{array}{c}\text { New Haven } \\
\text { Sacramento }\end{array}$ \\
\hline 1.25 & $\begin{array}{c}\text { Fairbanks } \\
\text { Hartford } \\
\text { Philadelphia } \\
\text { Washington, D.C. }\end{array}$ \\
\hline 1.30 & $\begin{array}{c}\text { San Diego } \\
\text { Juneau }\end{array}$ \\
\hline 1.35 & $\begin{array}{c}\text { Los Angeles } \\
\text { Boston } \\
\text { Trenton }\end{array}$ \\
\hline 1.40 & Honolulu \\
\hline 1.50 & $\begin{array}{c}\text { Chicago } \\
\text { Newark }\end{array}$ \\
\hline 1.75 & San Francisco \\
\hline 2.20 & New York \\
\hline
\end{tabular}

The relative cost of living data is derived from ACCRA COST OF LIVING INDEX, No. 2, at 1.2-.12 (2002).

\section{APPENDiX II. DERIVATION OF THE PROPER TAX MULTIPLIER}

This appendix derives the relative cost of living and relative salary multipliers - equations 5 and 6 - introduced in Part V. ${ }^{125}$

The optimality condition for the tax adjustment requires that the nominal dollar value of taxes be equal across regions. Thus,

$$
\tau=S_{i} m_{i} \tau
$$

where $\tau$ is the tax rate, $S_{i}$ is the relative before-tax salary in region $i$, and $m_{i}$ is the multiplier. The optimality condition implies that:

$$
m_{i}=\frac{1}{S_{i}} \text { or } S_{i}=\frac{1}{m_{i}},
$$

which establishes the relative salary multiplier given in equation 5 , which we call $m_{i}^{S}$. 
Equilibrium for individual taxpayers implies that their after-tax real incomes are equal. Thus,

$$
1-\tau=\frac{S_{i}\left(1-m_{i} \tau\right)}{C_{i}} .
$$

Substituting the optimality condition above for $S_{i}$ in the previous equation and rearranging terms yields:

$$
m_{i}=\frac{1}{C_{i}(1-\tau)+\tau},
$$

which establishes the relative cost of living multiplier given in equation 6 , which we call $m_{i}^{C}$.

\section{Appendix III. The Proper TAX Multiplier When TAX ReVenue IS PARTIALLY SPENT PROVIDING GOODS AND SERVICES AT THE LOCAL COST OF LIVING}

As described in Part V, when the tax revenue raised from each taxpayer with location-specific income is not spent at that taxpayer's local cost of living, efficiency requires that similar taxpayers pay the same nominal tax regardless of where they reside. In contrast, when the tax revenue raised from each taxpayer with location-specific income is spent at the taxpayer's local cost of living (so that its effectiveness is in inverse proportion to the taxpayer's local cost of living), then in equilibrium, each taxpayer's tax liability is in direct proportion to her cost of living. That is, efficiency requires that real taxes on location-specific income be constant across regions. Denoting the multiplier when all tax revenue raised from locationspecific income is spent on goods and services at the same cost of living by $m_{i}^{L}$, efficiency requires that:

$$
\tau=\frac{m_{i}^{L} S_{i} \tau}{C_{i}} .
$$

Rearranging terms and solving for $m_{i}^{L}$ yields:

$$
m_{i}^{L}=\frac{C_{i}}{S_{i}} \text {. }
$$

For regions with the average level of amenities, the multiplier will equal $1 .{ }^{126}$ Thus, for regions with average amenities, the flat tax schedule needs no adjustment and real taxes are constant across regions. For regions with above-average amenities, the multiplier exceeds 1 ; for those 
with below-average amenities, it is less than 1 . In all cases, tax liability will be in proportion to living costs. ${ }^{127}$

The tax revenue spent on employees at their local living costs might be less or more than the tax revenue raised from those employees. Denote by $p$ the ratio of the tax revenue spent on employees at their local living costs to the total tax revenue raised from such employees. The remainder, $1-p$, is that portion of tax revenue raised from employees that is not spent at those employees' local living costs. The efficiency-promoting multiplier when a portion $p$ of the tax revenue raised from employees is spent directly on employees at their local living costs is:

$$
(1-p) m_{i}^{S}+p m_{i}^{L} .
$$

The above multiplier is a weighted average of the multiplier when none of the revenue is spent at the taxpayers' local living costs and the multiplier when all of the revenue is so spent. The above multiplier reduces to $m_{i}^{S}$ when no tax revenue is spent at the taxpayers' local cost of living; it reduces to $m_{i}^{L}$ when all tax revenue raised from location-specific income is spent at the local cost of living of the taxpayers from whom it is raised.

127 If capital owners and those with non-location-specific income also receive benefits of equal real value that are purchased at their local costs of living, then efficiency requires that the real tax liabilities of taxpayers with the same nominal income be equal. Thus, the efficient multiplier to apply to each taxpayer's income would be her local cost of living, $C_{i}$ (not the reciprocal of her cost of living). 